J. Cin Chem Ctir. Bioctere

Vol 24. 1985. pp. 3-9

I. 1986 Walier de Gotyte \& Co.

Berin - Nier Yost

\title{
Enzyme Release from the Perfused Rat Heart The Functions of the Cytoskeleton under Cell-Pathological Conditions
}

\author{
By F. Diederichs, $K$. Mühlhous, $H$. Wintenberg and $I$. Trastschold
}

Abteikng Klinische Biochemie, Medi-inische Hochschule Hannover

(Recivad May 15 September 30, 1985)

In memoriam Professor Dr. Dr. Irar Trautschold (†31. 1. 1984)

Summary: The mechanism of enzyme release from Langendorff-periused rar hearts was studied under the injury conditions of the $\mathrm{Ca}^{2-}$ paradox and 24-dinitrophenol poisoning. During perfusion with Nrebs-Rirger buffer or in buffered sucrose sarcoplasmic enzymes were massively released when $\mathrm{Ca}^{2-}$ was reintroduced to the perfusion medium ( $\mathrm{Ca}^{2-}$ paradox). Mitochondrial matrix enzymes were released to a very small extent. Only the cytoplasmic isoenzyme of the bilocular enzyme malate dehydrogenase was released. The release kinetics of various enzymes with greatly differing molecular weights showed no significant difierences. Qualitatively the same results were obtained under 2,4-dinitrophenol poisoned conditions in $\mathrm{Ca}$--free suctose media. Sarcoplasmic enzymes were massively released, mitochondrial enzymes did not appear in the perfusate. 2,4-Dinitrophenol poisoning alone was not sufficient to cause enzyme release. An additional swelling under these conditions was necessary. ATP from the extracellular space was able to enhance the enzzme release. which was brought about by 2,4-dinitrophenol and cell swelling.

A hypothesis is presented that enzyme release is produced by initiating a membrane blebbing process. An elevated intracellular $\mathrm{Ca}^{2} \div$ concentration is a necessary prerequisite. In the presence of ATP. active memibrane blebbing is caused by contractions of the membrane-anchored cytoskeleton. In the absence of ATP passive membrane blebbing is induced by cell swelling, provided that the cytoskeleton has been crosslinked by $\mathrm{Ca}^{2} \div$.

Enzymaustritt am perfundierten Rattenherzen:

Die Funktionen des Zytoskeletts unter zellpathologischen Bedingungen

Zusammenfassung: Am Modell des isoliert perfundierten Rattenherzens wurde der Mechanismus des Enzymaustritts unter den Schädigungsbedingungèn dè $\mathrm{Ca}^{2}+$-Paradoxes and der 2,4-Dinitrophenol-Vergifung untersucht. Sowohl in Krebs-Ringer-Puffer als auch in Saccharose-Medium konnte ein erbeblicher Enzymaustritt festgestellt werden, wenn nach $\mathrm{Ca}^{2} \div$-freier Vorperfusion die $\mathrm{Ca}^{2} \div-\mathrm{Konzentration} \mathrm{des} \mathrm{Perfusionsmediums}$ abrupt wieder auf physiologische Werte erhöht wurde ( $\mathrm{Ca}^{2+} \div$-Paradox). Enzyme der Mitochondrien-Matrix trâten hierbei nur in geringem Maße aus. Von der biloculär auftretenden Malatdehydrogenase war nur das cytoplasmatische Isoenzym am Austritt beteilight. Die Austrittskinetiken verschiedener Enzyme zeigten unter den jeweiligen Bedingungen keine signifikanten Unterschiede, obwohl die entsprechenden Molekulargewichte erheblich voneinander abweichen. Bei 2,4-Dinitrophenol-Vergiftung und $\mathrm{Ca}^{2+}$-freier Perfusion mit gepufferten Saccharoselōsungen wurden qualitativ ähnliche Resultate erhalten; sarkoplasmatische Enzyme wurden in starkem Maße freigesetzt, während mitochondriale Enzyme nur geringfügig austraten. Die 2,4-DinitrophenolVergiftung war allein nicht hinreichend, einen Enzymaustritt zu verursachen, unter diesen Bedingungen mußte zusätzlich eine Zellschwellung erfolgen. Wenn jedoch eine Zellschädigung durch 2,4-Dinitrophenol-Vergiftung plus Schwellung erzeugt worden war, konnte diese durch Zusatz von ATP zum Perfusionsmedium erheblich verstärkt werden. 
Im Rahmen einer Hypothese wird der Mechanismus des Enzymaustritts als „membrane blebbing“-Prozeß dargestellt: Als notwendige Voraussetzung muß die intrazelluläre $\mathrm{Ca}^{2+}-\mathrm{Konzentration}$ erhöht sein. In Gegenwart von ATP wird ein aktives „membrane blebbing“ durch Kontraktionen des membranverankerten Zytoskeletts verursacht. Ist kein ATP vorhanden, kann ein passives „membrane blebbing“ durch Schwellung ausgelöst werden, wenn das Zytoskelett vorher durch $\mathrm{Ca}^{2+}$ vernetzt worden ist.

\section{Introduction}

A number of pathological conditions such as ischaemia, anoxia, cell poisoning etc., do not directly produce deleterious membrane alterations, but first of all lead to a deteriorated energy production and consequently to lowered ion gradients at cellular membranes. In an advanced state of these free enthalpy dissipating processes the permselective properties of the cell membrane disappear and finally soluble macromolecules, like cytoplasmatic enzymes, are released to the extracellular space. The colloidosmotic swelling theory of:Wilbrandt (1), or the hypothesis of Zierler $(2,3)$ of metabolically linked membrane pores cannot satisfactorily explain the phenomenon of enzyme release from injured cells. With the model of the isolated skeletal muscle, we have shown that cell swelling may be involved with cell injury, but is not the only mechanism to cause enzyme release. Likewise, a drastic decrease of the cellular ATP concentration by 2,4-dinitrophenol poisoning is not sufficient to destroy the permeability properties of the sarcolemma (4).

Meanwhile much experimental evidence has accumulated, which documents beyond any doubt that both skeletal and cardiac muscle cells during maturation develop a cytoskeleton, which is attached to the inner side of the sarcolemma by special protein filaments $(5-9)$. For a wide variety of other cell types it has been demonstrated that spectrin or spectrin-like polypeptides mediate this linkage between actin filaments of the cytoskeleton and the plasma membrane. The cellular functions of the cytoskeleton, however, are widely unknown. In particular, the participation of cytoskeletal filaments in cell-pathological processes, which are associated with an enzyme release, to our knowledge has only rarely been considered (10). We presented an hypothetical model for the mechanism of enzyme release from skeletal muscle $(4,11)$, which postulates that the reactions of a membrane-anchored cytoskeleton under appropriate conditions may generate membrane lesions by blebbing, whereby sarcoplasmic enzymes are squeezed out of the cell.

It was the aim of this study to investigate the mechanism of enzyme release employing the model of the isolated perfused rat heart under a variety of injury conditions, including the $\mathrm{Ca}^{2+}$ paradox (12) and 2,4dinitrophenol poisoning. Our results are consistent with a release mechanism, which is induced by $\mathrm{Ca}^{2+}$ triggered cross-linking and/or contractions of the membrane-linked cytoskeleton.

\section{Materials and Methods}

Male rats (HAN-WISTAR) weighing $300-350 \mathrm{~g}$ were anaesthetized with ether. To prevent blood clotting, $500 \mathrm{I}$. U. heparin were injected intravenously. The beating heart was quickly removed and transfered to ice-cold Krebs-Ringer buffer. The artery was then exposed and cannulated with polyvinyl chloride (PVC) tubing (i. d. $0.1 \mathrm{~cm}, 0$. d. $0.2 \mathrm{~cm}$ ). The coronary system was perfused with $10 \mathrm{ml}$ ice-cold buffer. To determine the wet weight $\mathrm{m}_{0}$ at time $t=0$, the heart was blotted on filter paper and weighed. Thereafter the aorta was cannulated and perfused with $5 \mathrm{ml} \mathrm{Krebs-Ringer} \mathrm{buffer} \mathrm{at} 37^{\circ} \mathrm{C}$. After a few seconds of perfusion the hearts began to beat again. The perfusion was accomplished on a double-reservoir non-circulating Langendorff apparatus (13). The flow rate during perfusion was $6 \mathrm{ml} /$ min at a perfusion pressure of about $8 \mathrm{kPa}$ and $20 \mathrm{kPa}$ of intact and injured myocards, respectively.

\section{Perfusion buffer}

Krebs-Ringer buffer $(\mathrm{mmol} / \mathrm{l})$

$\mathrm{NaCl} 118.0 ; \mathrm{KCl} 4.7 ; \mathrm{CaCl}_{2} 2.5 ; \mathrm{KH}_{2} \mathrm{PO}_{4} 1.2 ; \mathrm{MgSO}_{4}$ 1.2; tris(hydroxymethyl)-aminomethane (Tris) 20 .

Buffered sucrose solution (mmol/1)

Sucrose 250; Tris 20.

All perfusion media contained glucose $(10 \mathrm{mmol} / \mathrm{l}), 1 \mathrm{~g} / \mathrm{l}$ bovine serum albumin, and were gassed with oxygen for $60 \mathrm{~min}$. The $\mathrm{pH}$ was adjusted to 7.4 and osmolality, unless otherwise indicated, was about $300 \mathrm{mosmol} / \mathrm{kg} \mathrm{H}_{2} \mathrm{O}$.

\section{Enzyme catalytic activity concentration}

Lactate dehydrogenase (EC 1.1.1.27), glutamate dehydrogenase (EC 1.4.1.3) and aspartate aminotransferase (EC 2.6.1.1), were assayed according to the recommendations of the German Society of Clinical Chemistry (1972). Creatine kinase (EC 2.7.3.2) was determined according to the modification of Chemnitz et al. (14). For malate dehydrogenase (EC 1.1.1.37), aldolase (EC 4.1.2.13), isocitrate dehydrogenase (EC 1.1.1.42) and for phosphohexose isomerase (EC 5.3.1.9) commercial test kits were used (Boehringer Mannheim and Behring, respectively). Adenylate kinase (EC 2.7.4.3) was determined according to the method of Bergmeyer (15).

ATP was assayed enzymatically using commercial test kits (Boehringer Mannheim). All assays were run tat $25^{\circ} \mathrm{C}$. 


\section{Enzyme release}

Enzyme release was defined as the quotient of enzyme catalytic activity in the perfusate and the total catalytic activity of the myocard. Total catalytic activity was obtained by homogenising the tissue after perfusion in the respective perfusion buffer and adding the sum of released catalytic activity. Homogenisation was carried out in ice-cold buffer three times for $30 \mathrm{~s}$, with intervening intervals of $30 \mathrm{~s}$, by means of an Ultra-Turrax (JAHNKE + KUNKEL).

Perfusion with Krebs-Ringer buffer (control) showed no appreciable enzyme release (about $4 \%$ after $180 \mathrm{~min}$ ) from the beating isolated heart.

\section{Swelling}

Swelling was defined as the relative increase of wet weight $100 \%\left(m_{1}-m_{0}\right) / m_{0}\left(m_{0}=\right.$ wet weight before perfusion (see above), $m_{t}=$ wet weight after perfusion).

\section{Immunological differentiation}

The isoenzymes of malate dehydrogenase were determined using specific antisera obtained from sheep. The isolation of pure enzyme fractions was carried out according to the method of Mühlhaus (16).

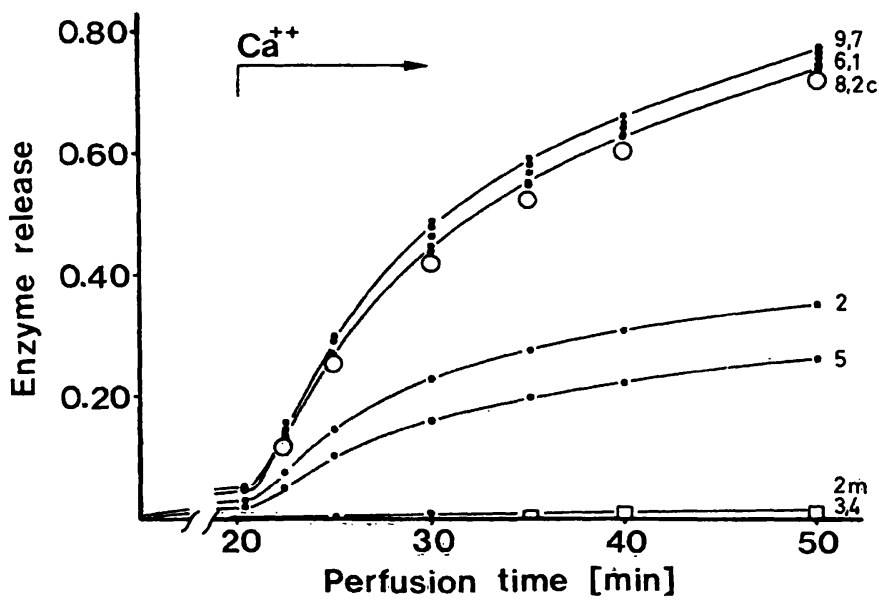

Fig. 1. Enzyme release (quotient of enzyme catalytic activity in the perfusate and the total catalytic activity of the myocard) during perfusion with Krebs-Ringer buffer under the conditions of the $\mathrm{Ca}^{2+}$ paradox. Perfusion sequence: $20 \mathrm{~min}$ of preperfusion with $\mathrm{Ca}^{2+}$-free $K r e b s$ Ringer buffer; from 20 to $50 \mathrm{~min}$ perfusion with KrebsRinger buffer +3.5 mmol/1 $\mathrm{Ca}^{2+}$.

$O$, release of cytoplasmic malate dehydrogenase;

$\square$, release of mitochondrial malate dehydrogenase.

Each point represents the mean of four hearts $(n=4)$, standard error of the mean (SEM) of the data did not exceed \pm 0.058 (SEM $\left.\leqslant \pm^{*} 0.058\right)$; swelling was negligible after preperfusion and was $(37.0 \pm 4.0) \%$ after $50 \mathrm{~min}$.

9 phosphohexose isomerase;

7 adenylate kinase;

6 creatine kinase;

1 lactate dehydrogenase;

8. aldolase;

2c malate dehydrogenase, cytoplasmic isoenzyme;

2 malate dehydrogenase;

5 aspartate aminotransferase;

$2 \mathrm{~m}$ malate dẹhydrogenase, mitochondrial isoenzyme;

3 isocitrate dehydrogenase;

4 glutamate dehydrogenase.

\section{Results}

\section{Enzyme release by the $\mathrm{Ca}^{2}+$ paradox}

Enzyme release from perfused rat hearts was induced under the conditions of the $\mathrm{Ca}^{2+}$ paradox using two perfusion.media of different composition. During 30 min of perfusion with Krebs-Ringer buffer of physiological ionic strength or with buffered sucrose of very low ionic strength, a strongly increasing enzyme release was induced when $3.5 \mathrm{mmol} / \mathrm{C} \mathrm{Ca}^{2+}$ was introduced to the media after a preperfusion period of 20 min in the "absence" $\left(\left[\mathrm{Ca}^{2+}\right]\right.$ ca $\left.5 \times 10^{-6} \mathrm{~mol} / \mathrm{l}\right)$ of extracellular $\mathrm{Ca}^{2+}$ (fig. 1 and 2). In both perfusion media the mobile enzymes of the sarcoplasm were released with very similar release kinetics, although the release characteristics under the two conditions differed markedly. In particular, there were no significant differences of release between enzymes of different molecular weights $\left(M_{\mathrm{r}}\right)$ (e. g. adenylate kinase $M_{\mathrm{r}}=0.21 \times 10^{5}$ and lactate dehydrogenase $M_{\mathrm{r}}=$ $1.4 \times 10^{5}$ ). In sucrose media the aldolase release was

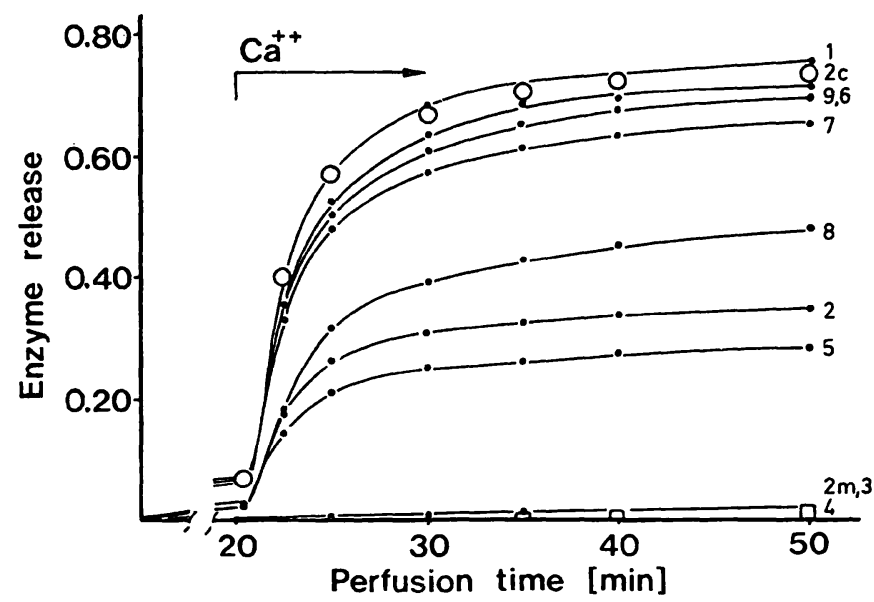

Fig. 2. Enzyme release (quotient of enzyme catalytic activity in the perfusate and the total catalytic activity of the myocard) during perfusion with buffered sucrose under the conditions of the $\mathrm{Ca}^{2+}$ paradox. Perfusion sequence: $20 \mathrm{~min}$ of preperfusion with $\mathrm{Ca}^{2+}$-free buffered sucrose; from 20 to 50 min perfusion with buffered sucrose + $3.5 \mathrm{mmol} / 1 \mathrm{Ca}^{2+}$.

0 , release of cytoplasmic malate dehydrogenase; $\square$, release of mitochondrial malate dehydrogenase. SEM $\leqslant \pm 0.073, n=4$; swelling was reduced from $(46.0 \pm 5.7) \%$ after $20 \mathrm{~min}$ to $(27.3 \pm 4.0) \%$ after $50 \mathrm{~min}$.

1 lactate dehydrogenase;

2c malate dehydrogenase, cytoplasmic isoenzyme;

9 phosphohexose isomerase;

6 creatine kinase;

7 adenylate kinase;

8 aldolase;

2 malate dehydrogenase;

5 aspartate aminotransferase;

$2 \mathrm{~m}$ malate dehydrogenase, mitochondrial isoenzyme;

3 isocitrate dehydrogenase;

4 glutamate dehydrogenase. 
significantly decreased, because under these conditions this enzyme is bound to myofibrillar proteins at low ionic strength (17). Bilocular enzymes like malate dehydrogenase and aspartate aminotransferase were released to a lesser degree. After immunological differentiation of malate dehydrogenase into the cytoplasmic and mitochondrial isoenzymes, however, the release kinetics of the isoenzymes paralleled those of the marker enzymes of the respective compartments. Mitochondrial matrix enzymes were released only to a very small extent.

In parallel experiments myocardial cell swelling (relative increase of wet weight) was measured during the course of the $\mathrm{Ca}^{2+}$ paradox. After 20 min of perfusion with $\mathrm{Ca}^{2+}$-free sucrose media swelling was $46 \%$, which was reduced to $27.3 \%$ after the subsequent 30 min of perfusion in the presence of $\mathrm{Ca}^{2+}$. McClellan et. al. (18) have shown that bundles of rat ventricular fibres become permeable to small ions and molecules when incubated in $\mathrm{Ca}^{2+}$-free media. Myocardial swelling in $\mathrm{Ca}^{2+}$-free sucrose media, therefore, was brought about by sucrose and water entry into the sarcoplasm of myocardial cells whose sarcolemma had become permeable to sucrose in the absence of extracellular $\mathrm{Ca}^{2+}$.

Enzyme release by 2,4-dinitrophenol poisoning

In contrast to the above results enzyme release was inhibited in 2,4-dinitrophenol poisoned Krebs-Ringer buffer under the perfusion conditions of the $\mathrm{Ca}^{2+}$ paradox. Significant swelling of myocards was not observed (fig. 3). Perfusion of rat hearts with $\mathrm{Ca}^{2+}$. free, 2,4-dinitrophenol containing sucrose media under the same conditions, however, produced a massive enzyme release just from the beginning of perfusion (fig. 4). Again, mobile sarcoplasmic enzymes were released with nearly identical kinetics, whereas the release of the mitochondrial matrix enzyme isocitrate dehydrogenase was negligible. The aldolase release under these conditions was strongly decreased presumably due to intracellular binding at low ionic strength (17) (see fig. 2). After $50 \mathrm{~min}$ of perfusion, myocardial swelling was $43.4 \%$.

When rat hearts were perfused with $\mathrm{Ca}^{2+}$-containing $(3.5 \mathrm{mmol} / \mathrm{l})$ sucrose media, the myocardial cell membrane remained impermeable whether or not 2,4dinitrophenol was present. Under these conditions the myocards were shrunken $(12.3 \%)$ because $\mathrm{KCl}$ and water left the cell to come into electrochemical equilibrium (no extracellular $\mathrm{KCl}$ ) without the compensatory sucrose entry that occurs under $\mathrm{Ca}^{2+}$-free

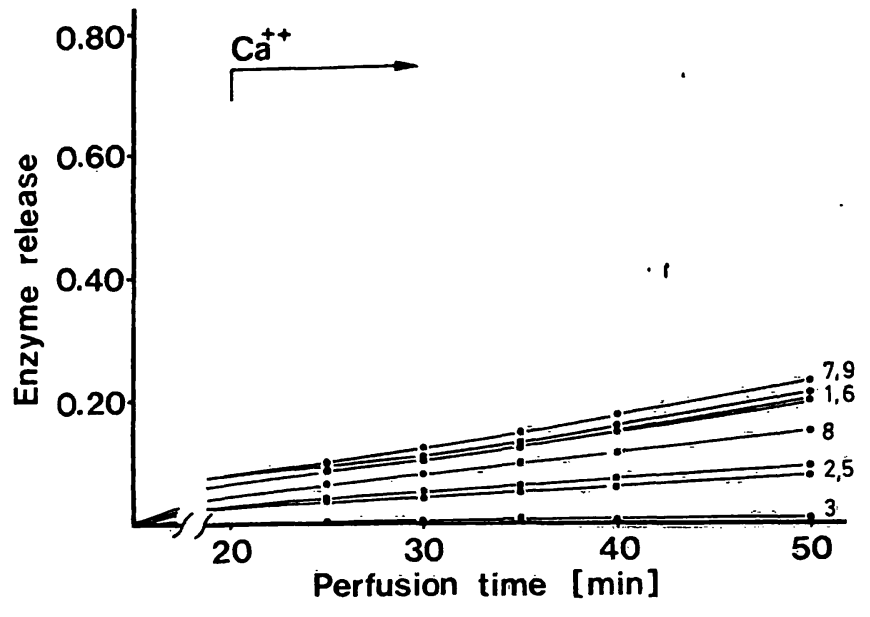

Fig. 3. Enzyme release (quotient of enzyme catalytic activity in the perfusate and the total catalytic activity of the myocard) during perfusion with 2,4-dinitrophenol containing Krebs-Ringer buffer under the conditions of the $\mathrm{Ca}^{2+}$ paradox. Perfusion sequence: 20 min of preperfusion with $\mathrm{Ca}^{2+}$-free Krebs-Ringer buffer $+0.5 \mathrm{mmol} / \mathrm{l}$ 2,4-dinitrophenol; from 20 to $50 \mathrm{~min}$ perfusion with Krebs-Ringer buffer $+0.5 \mathrm{mmol} / 1$ 2,4-dinitrophenol + $3.5 \mathrm{mmol} / 1 \mathrm{Ca}^{2+}$.

$\mathrm{SEM} \leqslant \pm 0.02, \mathrm{n}=4$; no significant swelling was observed. After $5 \mathrm{~min}$ [ATP] $\leqslant 9.25 \mu \mathrm{mol} / \mathrm{g}$ wet weight.

7 adenylate kinase;

9 phosphohexose isomerase;

1 lactate dehydrogenase;

6 creatine kinase;

8 aldolase;

2 malate dehydrogenase;

5 aspartate aminotransferase;

3 isocitrate dehydrogenase.

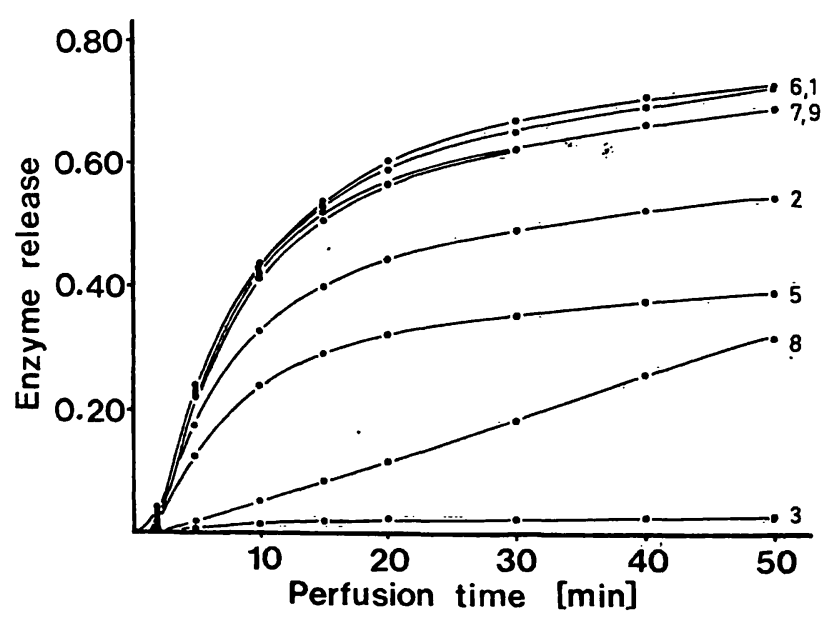

Fig. 4. Enzyme release (quotient of enzyme catalytic activity in the perfusate and the total catalytic activity of the myocard) during perfusion with $\mathrm{Ca}^{2+}$-free, 2,4-dinitrophenol containing buffered sucrose. Perfusion sequence: $50 \mathrm{~min}$ of perfusion with $\mathrm{Ca}^{2+}$-free buffered sucrose + $0.5 \mathrm{mmol} / 1$ 2,4-dinitrophenol.

SEM $\leqslant \pm 0.06, n=4$; swelling was $(43.4 \pm 2.7) \%$ after $50 \mathrm{~min}$.

6 creatine kinase;

1 lactate dehydrogenase;

7 adenylate kinase;

9 phosphohexose isomerase;

2 malate dehydrogenase;

5 aspartate aminotransferase;

8 aldolase;

3 isocitrate dehydrogenase. 
conditions. Enzyme release was not observed during 20 min of preperfusion with buffered isotonic sucrose. An abruptly increasing enzyme release, however, was initiated after replacing the isotonic preperfusion medium by a buffered hypotonic sucrose ( $84 \mathrm{mosmol} /$ $\mathrm{kg} \mathrm{H}_{2} \mathrm{O}$ ) of same composition (fig. 5).

In the absence of sarcoplasmic ATP under 2,4-dinitrophenol poisoned conditions ([ATP] $\leqslant 0.25 \mu \mathrm{mol} / \mathrm{g}$ wet weight after $5 \mathrm{~min}$ ) an elevated $\mathrm{Ca}^{2+}$ concentration of the sarcoplasm, obviously, was not sufficient to cause cell injury and enzyme release. An additional cell swelling was necessary to trigger enzyme release.

Under similar perfusion conditions (fig. 6) lactate dehydrogenase release was induced by sucrose swelling. After $20 \mathrm{~min}$ of preperfusion with 2,4-dinitrophenol containing buffered sucrose in the presence of $\mathrm{Ca}^{2+}$, the extracellular $\mathrm{Ca}^{2+}$ concentration was abruptly lowered by replacing the perfusion medium by $2,4-$ dinitrophenol containing buffered sucrose without $\mathrm{Ca}^{2+}$. Addition of $10 \mathrm{mmol} / 1$ ATP to this medium after preperfusion under the same conditions induced an even more drastically increasing lactate dehydrogenase release.

\section{Discussion}

\section{The membrane blebbing process}

Enzyme release from perfused rat heart was studied under various conditions of cell injury. In the same manner as for the releasse process from skeletal muscle (4), inhibition of ATP production alone was not sufficient to bring about an enzyme release from myocardial cells (fig. 3 and 5). An additional cell swelling was necessary to induce a drastic release. Likewise, swelling alone at a physiological ATP content of the cardiac cell did not produce an appreciable enzyme release (fig. 2 during preperfusion). Obviously, at least one further parameter must be involved with the generation of cell injury. In a subsequent publication (Diederichs \& Wittenberg in preparation) we shall present evidence from microelectrode studies (for detâils see 1. c. (19)) that under all studied conditions mêmbrane damage is preceded by an elevation of the sarcoplasmic $\mathrm{Ca}^{2+}$ concentration. Taking into account these facts, the following hypothesis about the mechanism of enzyme release from injured heart was presented (4): enzymes along with other soluble constituents of the sarcoplasm are squeezed out from the cell into the extracellular space by a transiently arising pressure gradient at different regions of the cell membrane. This outward directed gradient ( $v$ $\operatorname{grad} p, p=$ hydrostatic pressure, $v=$ volume of the

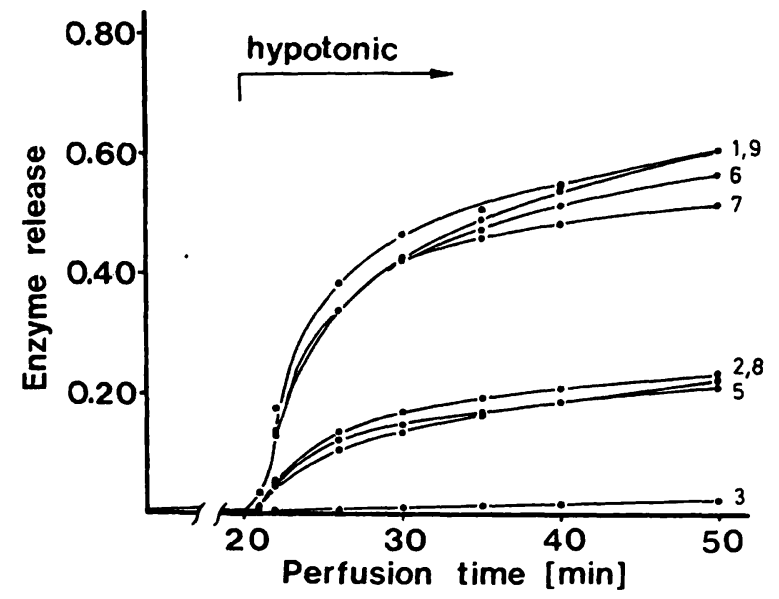

Fig. 5. Enzyme release (quotient of enzyme catalytic activity in the perfusate and the total catalytic activity of the myocard) during perfusion with $\mathrm{Ca}^{2+}$ and 2,4-dinitrophenol containing buffered sucrose under isotonic and hypotonic conditions. Perfusion sequence: $20 \mathrm{~min}$ of preperfusion with isotonic buffered sucrose +3.5 $\mathrm{mmol} / 1 \mathrm{Ca}^{2+}+0.5 \mathrm{mmol} / 1$ 2,4-dinitrophenol; from 20 to $50 \mathrm{~min}$ perfusion with hypotonic $(85 \mathrm{mosmol} / \mathrm{kg}$ $\mathrm{H}_{2} \mathrm{O}$ ) buffered sucrose $+3.5 \mathrm{mmol} / 1 \mathrm{Ca}^{2+}+0.5$ mmol/1 2,4-dinitrophenol.

SEM $\leqslant \pm 0.10, n=3$; swelling was $(-12.3 \pm 0.9) \%$ after $20 \mathrm{~min}$, and was $(14.6 \pm 3.4) \%$ after $50 \mathrm{~min}$. 1 lactate dehydrogenase;

9 phosphohexose isomerase;

6 creatine kinase;

7 adenylate kinase;

2 malate dehydrogenase;

8 aldolase;

5 aspartate aminotransferase;

3 isocitrate dehydrogenase.

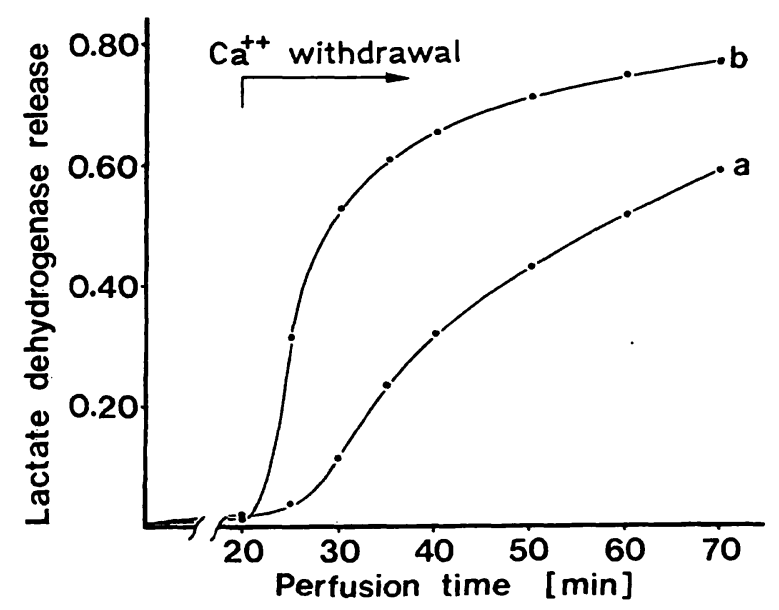

Fig. 6. Lactate dehydrogenase release (quotient of enzyme catalytic activity in the perfusate and the total catalytic activity of the myocard) during perfusion with 2,4dinitrophenol containing buffered sucrose; enhancing effect of added ATP on lactate dehydrogenase release induced by $\mathrm{Ca}^{2+}$ withdrawal from perfusion buffer. Perfusion sequence: $20 \mathrm{~min}$ of preperfusion with buffered sucrose $+0.5 \mathrm{mmol} / 1$ 2,4-dinitrophenol +3.5 mmol/1 $\mathrm{Ca}^{2+}$; from 20 to $70 \mathrm{~min}$ perfusion with $\mathrm{Ca}^{2+}$. free buffered sucrose $+0.5 \mathrm{mmol} / 1$ 2,4-dinitrophenol. a) without ATP, SEM $\leqslant \pm 0.054, n=6$; swelling was (28.8 \pm 5.2$) \%$ after $70 \mathrm{~min}$;

b) $10 \mathrm{mmol} / 1$ ATP, SEM $\leqslant \pm 0.043, \mathrm{n}=6$; swelling was $(19.8 \pm 3.3) \%$ after $70 \mathrm{~min}$. 
membrane) represents directly the driving force for the enzyme release process. It is brought about by the reactions of the membrane-anchored cytoskeleton (20). As a prerequisite the sarcoplasmic $\mathrm{Ca}^{2+}$ concentration must be elevated above a certain level (rat heart: $\left.\left[\mathrm{Ca}^{2+}\right]>10^{-5} \mathrm{~mol} / \mathrm{l}(19)\right)$. Then experimentally two possibilities can be distinguished.

1. In the absence of ATP cytoskeletal filaments are cross-linked by $\mathrm{Ca}^{2+}$ (or a Ca ${ }^{2+}$-dependent reaction), so that a relative rigid membrane-linked filament meshwork is produced. At this stage of reaction the cell membrane remains intact. If, however, an additional cell swelling is induced, the expanding sarcoplasm causes the smooth membrane phase to form bleb-like protrusions at regions, which are not anchored to the filament meshwork. During the course of progressive swelling a transiently arising pressure gradient must develop, when the membrane surface limits further volume expansion. But since the sarcolemma cannot withstand the increasing swelling pressure, transient membrane ruptures are formed, through which enzymes and other soluble sarcoplasmic material are squeezed out in the direction of the negative pressure gradient, i. e. into the extracellular space.

2. In the presence of ATP and an elevated $\mathrm{Ca}^{2+}$ concentration, the cytoskeletal filaments contract actively. Due to the incompressibility of the sarcoplasm the cell membrane analogously must be blebbed off from the skeleton. Under these latter conditions, however, cell swelling is not needed to induce membrane lesions.

\section{$\mathrm{Ca}^{2+}$ paradox}

During the preperfusion phase of the $\mathrm{Ca}^{2+}$ paradox the intracellular ATP and $\mathrm{Ca}^{2+}$ concentrations were in the physiological range $\left(\left[\mathrm{Ca}^{2+}\right] \mathrm{ca} 10^{-6} \mathrm{~mol} / \mathrm{l}(19)\right)$. Although there was a pronounced swelling after 20 min in sucrose media, enzyme release at this time interval was not increased (fig. 2). Swelling in the presence of ATP and a low $\mathrm{Ca}^{2+}$ concentration of the sarcoplasm, obviously, is not sufficient to cause severe cell injury. When extracellular $\mathrm{Ca}^{2+}$ is abruptly increased under these conditions, $\mathrm{Ca}^{2+}$ ions may enter the cell through the hyperpermeable sarcolemma (18) because of the steep inward driving electrochemical $\mathrm{Ca}^{2+}$ gradient. Influx via $\mathrm{Na} / \mathrm{Ca}$-exchange may also occur, particularly in sucrose media in the absence of extracellular $\mathrm{Na}^{+}$(lowered electrochemical potential difference of $\mathrm{Na}^{+}$over the membrane). Intracellular $\mathrm{Ca}^{2+}$ rapidly increases up to $10^{-4} \mathrm{~mol} / 1$ (19), whereby in the presence of ATP an active membrane blebbing may be induced with irreversible injury of the myocardial cell. In sucrose media enzyme release was even more pronounced, presumably because the myocards were already swollen during the preperfusion period. The striking volume decrease under these conditions is a strong indication of active cytoskeletal contractions, and a squeezing out of sarcoplasmic solution.

\section{2,4-Dinitrophenol poisoning}

In accordance with the results of Ruigrok et al. (21) enzyme release was inhibited in 2,4-dinitrophenol poisoned Krebs-Ringer buffer under the perfusion conditions of the $\mathrm{Ca}^{2+}$ paradox. In 2,4-dinitrophenol poisoned myocardial cells the sarcoplasmic ATP concentration is strongly reduced by uncoupling the respiratory chain of mitochondria from ATP synthesis. The intracellular $\mathrm{Ca}^{2+}$ concentration under these conditions is elevated to more than $10^{-5} \mathrm{~mol} / \mathrm{l}$ (19), although the extracellular concentration is low $\left(5 \times 10^{-6} \mathrm{~mol} / \mathrm{l}\right.$ in Ca-free media). Presumably, $\mathrm{Ca}^{2+}$ is released from the sarcoplasmic reticulum and from mitochondria. When ATP is exhausted the increased $\mathrm{Ca}^{2+}$ concentration in the sarcoplasm cannot produce membrane blebbing and enzyme release (fig. 3 ). Now a further swelling is necessary to blebb off the membrane from the cross-linked filament meshwork (fig. 4). This passive membrane blebbing may be induced by sucrose and water entry through the permeabilised sarcolemma. The cross-linking by $\mathrm{Ca}^{2+}$ and the induction of injury by a subsequent swelling is better resolved under the experimental conditions of figure 5. The intracellular $\mathrm{Ca}^{2+}$. concentration is expected to be even more increased, because extracellular $\mathrm{Ca}^{2+}$ was present. The sarcolemma remained impermeable to sucrose although the myocard was in the rigor state. Only the water permeability of the sarcolemma, like that of other biological membranes, is quite high. In accordance with a blebbing mechanism swelling by water inflow after cross-linking of the cytoskeleton must induce enzyme release. The presence of extracellular $\mathrm{Ca}^{2+}$ seems to be of secondary importance to the membrane damaging reactions.

When the sarcoplasmic $\mathrm{Ca}^{2+}$ concentration is increased (cross-linked cytoskeletal filaments) ATP from the extracellular compartment appreciably enhanced the release process (fig. 6). Concerning the $\mathrm{O}_{2}$ paradox, it is not clear wether ATP is involved in the generation of cell injury $(22-24)$. Our results show clearly that ATP under the conditions employed paradoxically could increase cellular destruction. Supposedly, ATP can enter the sarcoplasm by diffusion through the hyperpermeable sarcolemma. In the presence of an elevated intracellular $\mathrm{Ca}^{2}+$ iconcentration 
contractions of the cytoskeleton are induced, so that an active membrane blebbing is initiated. The filament lattice of the myofibrils was already contracted (rigor state) during the preperfusion period and there was no further visible contraction of whole myocard after addition of ATP. Nevertheless, swelling was significantly reduced in the presence of ATP. Therefore, it seems more reasonable to suggest that ATP in the presence of high intracellular $\mathrm{Ca}^{2+}$ had contracted the membrane-anchored filaments of the cytoskeleton, rather than the rigor-contracted actomyosin filaments of fibrils. In this view the destructed myofibrils, which are visible after injury by the $\mathrm{Ca}^{2+}$ paradox and which have been interpreted to result from abnormal contractures of myofibrils (25), in our opinion are created by the action of contractile filaments of the cytoskeleton, whereby the highly ordered organisation of the fibrillar filament lattice becomes disrupted too.

\section{Kinetics of enzyme release}

Under the various conditions of injury, different time courses of enzyme release were observed. Under given conditions, however, there were only small mutual differences between the release kinetics of the respective enzymes. These characteristics of enzyme release cannot be explained by a diffusion or permeation process through a leaky membrane, because there is no dependence of enzyme release on molecular weights. The membrane blebbing hypothesis, however, can easly explain these facts: mobile enzymes of the sarcoplasm are squeezed out of the cell by a

\section{References}

1. Wilbrandt, W. (1941) Pflügers Arch. Ges. Physiol. 245, 22-31.

2. Zierler, K. L. (1956) Am. J. Physiol. 185, 1-11.

3. Zierler, K. L. (1957) Am. J. Physiol. 190, 201-205.

4. Diederichs, F., Mühlhaus, K., Trautschold, I. \& Friedel, R. (1979) Enzyme 24, 404-415.

5. Repasky, E. A., Granger, B. L. \& Lazarides, E. (1982) Ceell $29,821-833$.

6. Lazarides, E. \& Nelson, W. J. (1982) Cell 31, 505-508.

7. Nelson, W. J. \& Lazarides, E. (1983) J. Cell Biol. 97, 967.

8. Pardo, J. V., D'Angelo Siliciano, J. \& Craig, S. W. (1983) J. Cell Biol. 97, $1081=1088$.

9. Dlugosz, A. A., Antin, P. B., Nachmias, V. T. \& Holtzer, H. (1984) J. Cell. Biol. 99, 2268-2278.

10. Trump, B. F., Berezesky, I. K., Phelps, P. C. \& Sato, T. (1983) J. Cell Biol. 97, 1043.

11. Friedel, R., Diederichs, F. \& Lindena, J. (1979) In: Advances in clinical enzymology (Schmidt, E., Schmidt, F. W., Trautschold, I. \& Friedel, R., eds.), pp. 70-106, S. Karger, Basel.

12. Żimmermann, A. N. E., Daems, W. D., Hülsmann, W. C., Snijder, I., Wisse, E. \& Durrer, D. (1967) Cardiovasc. Res. 1, $201-209$.

13. Langendorff, O. (1895) Arch. Ges. Physiol. 61, 291-332.

14. Chemnitz, G., Schmidt, E., Koller, P. V. \& Bush, E. W. (1979) Dtsch. Med. Wochenschr. 104, 257-260. developing pressure gradient over the cell membrane, so that the quantity appearing outside only depends on the concentration inside the cell.

In relation to the control of cell volume under more physiological conditions, a moderate blebbing would be of advantage compared with an osmotic process of volume decrease. Since, e.g. the concentrationdependent phosphate potential $\left(-\Delta \mathrm{G}_{\mathrm{ATP}}\right)$ of the cytoplasm during the squeezing out of cytoplasmic solution would not change, whereas during the loss of water along with certain ions, $-\Delta \mathrm{G}_{\text {ATP }}$ would decrease, i. e. recovery from "reversible" injury would be energetically more difficult.

\section{Enzyme release from mitochondria}

Under all injury conditions, the studied mitochondrial matrix enzymes appeared only to a negligible extent in the perfusate. This may be explained by our observation (not published), that these enzymes are released when $\mathrm{Ca}^{2+}$ and phosphate are accumulated by energized mitochondria in the absence of ADP. The ADP concentration of injured myocardial cells, however, at least during the observed time courses, is sufficiently elevated to inhibit the release of matrix enzymes.

\section{Acknowledgement}

The authors thank Mrs. Hannelore Burkhardt for the excellent technical assistence.

This work was supported by the Deutsche Forschungsgemeinschaft.

15. Bergmeyer, H. U., Gawehn, K. \& Graßl, M. (1974) In: Methoden der enzymatischen Analyse (Bergmeyer, H. U., ed.), pp. 517-518, Weinheim.

16. Mühlhaus, H. (1981) Thesis, Medical School Hannover.

17. Pette, D. (1975) Acta Histochem. Suppl. 14, 47-68.

18. McClellan, G. \& Winegrad, S. (1978) J. Gen. Pysiol. 72, $737-767$.

19. Wittenberg, H. (1985) Thesis, University Hannover.

20. Albrecht-Buchler, G. (1982) Cold Spring Harbor Symposia of quantitative biology XLVI Part I, 45-51.

21. Ruigrok, T. J. C., Bouik, A. B. T. J., Spies, F., Blok, F. J., Maas, H. A. J. \& Zimmerman, A. N. E. (1978) J. Molec. Cell. Cardiol. 10, 991-1002.

22. Hearse, D. J., Humphrey, S. M. \& Chain, E. B. (1973) J. Molec. Cell. Cardiol. 5, 395-407.

23. Nayler, W. G., Poole-Wilson, P. A. \& Williams, A. (1979) J. Molec. Cell. Cardiol. 11, 683-706.

24. Ganote, C. E., McGarr, J., Liu, S. Y. \& Kaltenbach, J. P. (1980) J. Molec. Cell. Cardiol. 12, 387-408.

25. Ganote, C. E., Liu, S. Y., Safavi, S. \& Kaltenbach, P. (1981) J. Molec. Cell. Cardiol. 13, 93-106.

Dr. rer. nat. Frank Diederichs, Abteilung für Klinische Biochemie Medizinische Hochschule Hannover Konstanty-Gutschow-Straße 8 D-3000 Hannover 61 


\section{.}

